"The impact of the independent review on SME access to bank finance: the case of South Africa"

\begin{tabular}{|c|c|c|}
\hline AUTHORS & \multicolumn{2}{|l|}{$\begin{array}{l}\text { Francois Coetzee } \\
\text { Pieter W. Buys }\end{array}$} \\
\hline ARTICLE INFO & \multicolumn{2}{|c|}{$\begin{array}{l}\text { Francois Coetzee and Pieter W. Buys (2017). The impact of the independent } \\
\text { review on SME access to bank finance: the case of South Africa. Banks and } \\
\text { Bank Systems, } 12(1-1), 135-142 \text {. doi:10.21511/bbs.12(1-1).2017.06 }\end{array}$} \\
\hline DOI & \multicolumn{2}{|c|}{ http://dx.doi.org/10.21511/bbs.12(1-1).2017.06 } \\
\hline RELEASED ON & \multicolumn{2}{|l|}{ Wednesday, 26 April 2017} \\
\hline RECEIVED ON & \multicolumn{2}{|l|}{ Monday, 20 February 2017} \\
\hline ACCEPTED ON & \multicolumn{2}{|l|}{ Thursday, 23 March 2017} \\
\hline LICENSE & \multicolumn{2}{|c|}{$\begin{array}{l}\text { This work is licensed under a Creative Commons Attribution-NonCommercial } 4.0 \\
\text { International License }\end{array}$} \\
\hline JOURNAL & \multicolumn{2}{|l|}{ "Banks and Bank Systems" } \\
\hline ISSN PRINT & \multicolumn{2}{|l|}{ 1816-7403 } \\
\hline ISSN ONLINE & \multicolumn{2}{|l|}{$1991-7074$} \\
\hline PUBLISHER & \multicolumn{2}{|c|}{ LLC "Consulting Publishing Company "Business Perspectives" } \\
\hline FOUNDER & \multicolumn{2}{|c|}{ LLC "Consulting Publishing Company "Business Perspectives" } \\
\hline \multirow[b]{2}{*}{ NUMBER OF REFERENCES } & & 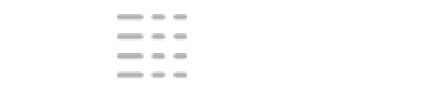 \\
\hline & NUMBER OF FIGURES & NUMBER OF TABLES \\
\hline 50 & 0 & 1 \\
\hline
\end{tabular}

(C) The author(s) 2023. This publication is an open access article. 
Francois Coetzee (South Africa), Pieter W. Buys (South Africa)

\title{
The impact of the independent review on SME access to bank finance: the case of South Africa
}

\begin{abstract}
It is accepted that SMEs are major contributors to global employment and GDP. Similarly, SMEs' reliance on bank finance to maintain financial and operational sustainability is also globally accepted. In 2008, the Company's Act of South Africa was amended to scrap the statutory audit requirement for qualifying entities, with the aim of alleviating the administrative burden of SMEs and increase their sustainability potential. As sound as this strategy may have been, a grey area arose in that banks may still insist on audited financial statements. This study investigates the question as to whether South African banks still consider audited financial statements as key in evaluating SME bank finance applications. This was done by analyzing the major banks' requirements per their policies and follow-up discussions with loan officers. Contrary to expectations, the historic focus per audited financial statements was considered of much less importance than progressive future-oriented management statements and reports.
\end{abstract}

Keywords: audit, independent review, SME finance, SME sustainability.

JEL Classification: M13, M41, M42, M48.

Received on: $20^{\text {th }}$ of February, 2017.

Accepted on: $23^{\text {th }}$ of March, 2017.

\section{Introduction}

"Double, double toil and trouble; fire burn, and cauldron bubble" the witches cackled in Shakespeare's Macbeth (Shakespeare, 1985, 4.1:10).

If we did not know any better, one may be excused for thinking Shakespeare was bemoaning the plight of the small and medium enterprises (SMEs) of old. The SMEs drive for sustainability is a topic of substantial interest to contemporary academic management researchers and practitioners. In the South African context, the Global Entrepreneurship Monitor found that the entrepreneurial activity (often the SME domain) in South Africa has dropped by $34 \%$ in the 10 years leading up to 2014 (GEM, 2014). This research also found that entrepreneurial confidence is very low compared to the rest of Sub-Saharan Africa. This translates into a perception that entrepreneurs are often not confident that they can successfully start a sustainable business in South Africa, which does not inspire much confidence in South Africa's SME market.

According to the Bankseta (n.d.), in order for SMEs to be sustainable in the contemporary global market environment, they have to be able to:

- attract and retain skilled managers and personnel;

- access to their intended markets;

- build customer relationships;

- access to the best-suited technologies;

(C) Francois Coetzee, Pieter W. Buys, 2017.

Francois Coetzee, Ph.D. Candidate, NWU School of Business and Governance, North-West University, Potchefstroom, South Africa.

Pieter W. Buys, Professor, WorkWell Research and NWU School of Business and Governance, North-West University, Potchefstroom, South Africa.

This is an Open Access article, distributed under the terms of the Creative Commons Attribution-NonCommercial 4.0 International license, which permits re-use, distribution, and reproduction, provided the materials aren't used for commercial purposes and the original work is properly cited.
- access to sufficient production capacities;

- be attentive to their role in social and economic development;

- access to finance and credit.

An interesting point to ponder when scrutinizing the above is that attracting skilled personnel, gaining access to markets, accessing to technologies and having sufficient production capacities are all dependent on the SME having adequate access to finance, which may lead us to assume that access to finance may well be the major constraint faced by contemporary SMEs.

The above is reiterated by Ayyagari et al. (2012) and Beck et al. (2005) who all consider the ability of SMEs to grow and be sustainable to be very much dependent on their access to finance. Banks, however, have historically often regarded SMEs as of a higher risk profile than larger corporations, especially when it comes to granting finance (Mazaroll, 2012; Haynes et al., 1999). Therefore, when applying for bank finance, SMEs historically underwent a more rigorous scrutiny process, which entailed mitigating such risk by requiring audited financial statements in order to extrapolate the required risk assessment tools when applying for finance (SAICA, 2010). As such, audited financial information has historically been used to provide banks with better assurances of reliance on business information.

In the contemporary South African business environment, the advent of the new Companies Act, No. 71 of 2008 (referred to as the Act hereafter) has brought about the abolishment of the statutory audit requirement for qualifying companies (typically then SMEs) and has introduced the new concept of the 'independent review' (Act, 2008). According to SAIPA (2011), an independent review is an engagement by which an accountant external to the 
entity provides a limited assurance review on a set of financial statements. Under current legislation, qualifying entities have the option to choose between either i) an independent review or ii) a conventional audit. This has caused a dilemma for SMEs. Choosing the independent review route will save them a substantial amount on auditing fees, but might jeopardize their access to bank funding. The flip side of the coin is to bear the cost of a more expensive audit fee in the hope of improving their chances of accessing to bank funding. As important as bank funding may be to SMEs, the cost of an audit, compared to the cost of an independent review, will surely be a major consideration when deciding which route to follow.

Abdor and Quartey (2010) and Bankseta (n.d.) estimate that more than $90 \%$ of formal business entities in South Africa are SMEs, while contributing up to $57 \%$ of the national GDP and as much as $61 \%$ of employment. Taking i) the value that SMEs contribute to South Africa's economy into account, ii) the fact that South Africa is currently struggling with unemployment, and iii) the plight of the SME to be sustainable, it is evident that having adequate access to funding needs to be taken very seriously (Claymore, 2016; Bernstein, 2016).

\section{Literature review}

1.1. Defining the SME concept. Even though the concept of Small and Medium Enterprises (SME) is globally acknowledged, there does not seem to what an SME actually is. Notwithstanding, in terms of its characteristics, Malhotra et al. (2007) refer to independent business entities that have a manager/owner structure, while also expressing the opinion that the number of employees is the most common way of defining whether an entity is classified as an SME or not. Mahembe (2011), in turn, comments that SMEs are defined either with reference to the number of employees, or to the value of annual turnover, or a combination thereof. Consequently, the World Bank (2002; 2004) classifies SMEs as business entities with a maximum of 300 employees, less than U\$15 million in annual turnover and less than U\$15 million in assets.

In a South African survey by Fin Mark (2010), SMEs were defined as business entities with an owner who is at least 16 years old, generates an income through small business activities and employs fewer than 200 employees. Falkena et al. (2001) extend this definition within a South African context by adding a turnover not exceeding ZAR ${ }^{1} 50$ million. Even though it is evident that different economic regions may have their own definition of

${ }^{1}$ ZAR being South African rand and the local currency. At the time of writing the exchange was approximately U\$1 = ZAR13.40. what an SME is, what does remain constant is the fact that the intended thing being defined remains the same, i.e., a business entity that is smaller than the so-called big companies and corporations. For the purpose of this paper, SMEs will be viewed as a business entity that is a closely held business entity, i.e. with a manager/owner organizational structure with fewer than 200 employees.

1.2. The economic role of SMEs. Economists and business experts agree that SMEs are very often key drivers of economic growth through job creation, increased exports and imports, and increasing production volumes (Mahembe, 2011; Ayyagari et al., 2007). Furthermore, SMEs internationally seem to have a standard pattern of involvement in economies, for example:

- SMEs in Japan employ approximately $69 \%$ of the domestic workforce and contribute approximately $60 \%$ to the GDP (Robu, 2013).

- SMEs in the European Union employ up to twothirds of the domestic workforce and contribute up to $52 \%$ to GDP (Robu, 2013).

- SMEs in the UK employ approximately $60 \%$ of all private sector employment and contribute $47 \%$ to all private sector turnover (FSB, 2016).

- SMEs in Canada employ up to $70 \%$ of the total private workforce, while contributing between 25 and $41 \%$ of the GDP (Industry Canada, 2013).

- SMEs in the USA employ approximately 58\% of the private workforce and contribute approximately 65\% to the GDP (Robu, 2013).

- SMEs in South Africa account for as much as $91 \%$ of formal business, contribute up to $57 \%$ to GDP and employ close to $61 \%$ of the domestic workforce (Abor \& Quartey, 2010).

It is, therefore, obvious that the sustainability of the SME sector should be of paramount importance to policy-makers, economists and academics globally. A flourishing SME sector should ultimately contribute to stimulated economic growth and job creation. The inverse, however, is also true. If SMEs are not enabled to be sustainable, the economic repercussions on the (un-)employment and GDP levels can be crippling. If financing is considered to be one of the most important factors impeding SME growth, economic policy and regulations must endeavor to make access to funding less inhibiting to SMEs.

1.3. The importance of bank finance. Malhotra et al. (2007) state that literature on corporate finance indicates that the lack of finance is a key obstacle to company growth. Wattanapruttipaisan (2003) extends this viewpoint to an SME perspective and states that access to finance is one of the main reasons why SMEs often struggle. According to Mills and McCarthy (2014), bank loans (as a form of finance) have always been of 
crucial importance to SMEs. Research also indicated that more than $80 \%$ of SMEs regard banks as their primary source of business funding (NFIB, 2012; Mahembe, 2011). However, although bank finance seems to be the most preferred source of SME financing, Mazanai and Fatoki (2012) found that only approximately $30 \%$ of SME financing applications are eventually approved.

\subsubsection{Accessibility of bank finance: an SME per-} spective. In interviews with various accounting firms, the ICAEW (2009) found that partners were often of the opinion that their SME clients found access to finance difficult. The severity here of was described as from fairly difficult to the belief that banks just were not lending anymore. There is a saying that the bank will loan you as much money as you want as soon as you can prove that you do not need the loan. Although this statement may be considered as facetious, the OECD (2009), nonetheless, considers access to finance as one of the most significant challenges for SMEs' sustainability.

- From a global perspective, the overwhelming consensus is that SMEs are indeed facing tough credit conditions (European Union, 2002). Maudos (2013) endorses this view by providing the following international data:

- In Portugal, $45 \%$ of SMEs considered banks as being reluctant to provide credit, while $38 \%$ of Irish SMEs shared this viewpoint.

- In Spain, as much as 27\% of SMEs indicated that access to finance is their most serious problem, while more than $57 \%$ considered the banks as being reluctant to provide credit.

- In Greece, as much as 31\% of SMEs indicated that access to finance is their most serious problem, while $49 \%$ considered the banks as being reluctant to provide credit.

- Although not as severe, $10 \%$ of German SMEs and $13 \%$ of French SMEs indicated that access to finance is their most serious problem.

- From a South African perspective, accessing finance is also one of the main constraints listed by several surveys and SME studies (Mahembe, 2011; Berry et al., 2002; Fatoki \& Garwe, 2010; Chimucheka \& Rungani 2011). Research conducted by Fatoki and Asah (2011) indicated that $91 \%$ of SMEs surveyed stated that they needed external finance from a commercial bank for i) working capital $(40 \%)$, ii) to invest in fixed assets $(57 \%)$, and iii) for business acquisitions (3\%). Notwithstanding such needs, only $39 \%$ successfully applied for finance.
From the above statistics, we can gauge that financing constraints are not unique to certain countries or even demographic areas, but is, in fact, a global phenomenon.

1.3.2. Availability of bank finance: A bank perspective. While SMEs may be of the opinion that banks are simply not making finance available, bankers blame i) SME owners for a lack of demand for credit products and ii) the regulators for requiring more stringent criteria when approving SME loans (Wiersch \& Shane, 2013). As such, it may very well be that banks make less credit available because they themselves are struggling to raise funds and are also taking some strain due to inter-bank lending constraints (OECD, 2009). Not only has the recent global economic crises compounded SME sustainability difficulty by creating a drop in demand for goods and services across the board, but also placing strain on bank finance availability by tightening credit terms. This has caused access to funding in the SME market space to become very tight (SBA, 2011).

Mills and McCarthy (2014) confirm this trend when they argue that banks are often either too strict when considering funding applications or are outright unwilling to provide funding. In defence of the banking sector, one can argue that the high failure rate of SMEs may be a reason why access to credit is difficult, as the risk profile of SMEs is somewhat tarnished (Mazanai $\&$ Fatoki, 2012). There are of course several other reasons why SMEs may find access to finance harder, which, according to Malhotra et al. (2007), include i) the unpractical policies in the financial sector (e.g., higher interest rates), ii) the lack of SME-related expertise at banks, iii) the inherent higher risks associated with SMEs, and iv) information asymmetries, such as no statutory requirement for audited financial statements. These reasons are supplemented by Mazanai and Fatoki (2012) who identify i) high administrative costs of small-scale lending, ii) asymmetric information, iii) high risk perception, and iv) lack of collateral as key reasons why banks may be reluctant to give loans to SMEs.

1.3.3. The SME finance gap. A key reason for the discrepancy between what SMEs seem to be claiming and what banks are rebutting with could be attributed to a finance gap. Simply put, it implies that there are a number of viable SMEs that are unable to obtain funding from banks. This financing gap, according to Mazanai and Fatoki (2012), can be as large as $80 \%$ in OECD countries and as large as $90 \%$ in non-OECD countries. Asymmetry of information is a key aspect impeding SMEs in accessing bank finance (Stiglitz \& Weiss, 1981). This implies that banks have to evaluate applications without understanding the dynamics of an SME's business 
model and performances, leaving them to make best guess evaluations in such applications. Obviously, with banks not being in the risk-taking business, it will lead to decisions under moral hazard and adverse risk conditions (Mazanai \& Fatoki, 2012).

Turton and Herrington (2012) and Mahembe (2011) state that South African SMEs have constrained access to the financing they need. A survey done by FinMark (2010) indicates that although an average of $84.4 \%$ of SMEs applied for bank loans, only $33.3 \%$ of these loans were successful. This data supports the perception that there is a real, significant finance gap in South Africa.

\subsection{The relevance of audits in SMEs accessing} bank finance. 1.4.1. To audit or not to audit? The preceding discussions have established that access i) to finance is of paramount importance to ensure SME sustainability, ii) that problems related thereto is a universal problem, iii) that bank financing, per se, is a crucial part of the SME financing culture and iv) that there is a perception that banks are too strict in their lending criteria. Banks, on the other hand, seem to be of the opinion that unsuccessful financing applications are to be blamed on various external factors that influence their risk assessments and analysis of the applicant's information. With the abolishment of the statutory audit requirement for qualifying companies in South Africa the question that needs to be answered is whether this will further increase the problem of asymmetric information and thereby further impede an SME's chances of obtaining access to financing.

Research conducted by Berger and Udell (2006) concluded that banks are very active users of financial statements and will more often than not require financial statements when considering an application for financing - be it audited, reviewed or at merely compiled by suitably certified/licensed accountants. Nevertheless, there seem to be conflicting viewpoints on the aspect of the value banks may or may not attribute to audited financial statements.

- On the one hand, it is argued that the role of an audit is to give the users of the financial statements a reasonable assurance that the information is presented reliably and fairly. Collis et al. (2013) state that financial institutions in South Africa often require audited financial statements when considering a loan application. Wignaraja and Jinjarak (2015) also found that audited financial statements had a mostly positive effect on bank loan applications, while Tsaia and Huab (2009) and Kim and Elias (2008) found that audited financial statements had a positive effect on the interest rates attached to approved finance applications.
- In somewhat conflicting findings, Wright and Davidson (2000) indicate that the auditor's attestation did not have an effect on the bank's decisionmaking process. Furthermore, Kim and Elias (2008) found that during interviews with senior lending officers, audited financial statements were often not required. Although this may be because smaller banks may fashion their loan criteria on a more personal, soft approach, i.e., knowledge about the owner and the business, the fact remains that audited financial statements were not required. In contrast, larger banks may tend to focus more on hard information, i.e., information that can be verified somehow. Studies have further found that the attestation report only comes into play when it indicates a situation in direct contrast to healthy financial statements (Guiral-Contreras et al., 2007).

1.4.2. The value of an audit. Berger and Frame (2005) raise the point that one of the reasons larger business entities may find access to finance easier is because their information is not regarded as opaque, as is the case with smaller business entities. An important reason for this is because larger firms have access to audited financial information on a regular (statutory) basis. SMEs, on the other hand, tend to suffer from opaque information, which places them in the precarious position of providing the lenders with enough information to requirements. Therefore, due to SME information often being regarded as opaque and asymmetric, banks may be more reluctant to approve loan requests if audited financial statements are not provided. Because the information is regarded as third-party reviewed, a loan officer may regard audited financial information as of greater importance when checking for reliable information (Le, 2012; Kim \& Elias, 2008; Feschijan, 2008).

Taking it one step further, research conducted by Wignaraja and Jinjarak (2015) and Mahembe (2011) found that business entities using external audit reports were more likely to have credit available and have a better chance of successfully applying for loans. Furthermore, a survey done by IFAC (2010) confirmed that lenders highly value audited financial statements and regard the audit function as key in reducing information asymmetry. In further support of the audit importance within this context, one of the methods used by banks to evaluate a loan application is called financial statement lending, in which loans are evaluated primarily based on the financial statements of the borrower. This obviously requires trustworthy financial statements, which audited financial statements as such provide. For SMEs with transparent financial information, this method provides some distinct advantages, and the opaque information dilemma is nullified quickly and reasonably cost-effectively (Berger \& Udell, 2004). 
The above arguments support the premise that audited financial statements may be advantageous to SMEs. As sound as this reasoning may be, the changes to the auditing landscape brought about by the Act would have forced banks to adapt and modify their approach to SME lending practices.

\section{The purpose of the paper}

With the advent of the independent review and the abolishment of the statutory audit requirement for qualifying companies in South Africa, banks may become more stringent in their evaluation of bank finance applications to compensate for the perception that unaudited financial information may be less reliable than audited financial information. In evaluating finance applications, therefore, banks may i) request more information to be presented, ii) justify the perceived risk by raising interest rates, iii) attach stricter finance terms, iv) require more collateral, or v) even decline the finance application outright. All of the above actions may have far-reaching ramifications as far as the sustainability of SMEs is concerned. It is, therefore, crucially important for South African SMEs' owners/managers to understand whether the choice between an independent review and a conventional audit may have any potential negative ramifications as far as accessibility to bank finance is concerned. SMEs may very well be caught between a rock and a hard place in that if it decides not to audit its financial statements, the SME might end up with devastating cashflow challenges. The inverse is also possible and an SME might choose to audit its financial statements at great cost, but have a bank that does not place much value on whether the financial statements are audited or not when assessing credit applications. One might summarize the problem SMEs face by asking: "To audit or not to audit, that is the question".

\section{Research method}

Within the context of South African SMEs, and in light of the aforementioned, this paper's research problem focuses on whether it is prudent for SMEs to have their financial statements audited or not. The purpose of this investigation was to determine the value that South African banks place on audited financial statements when considering funding applications from SMEs. In order to establish this, the informational requirements from four of the biggest banks in South Africa were analyzed. According to data published in 2014, these four banks represented $82 \%$ of the banking market share of South Africa at the time (The Banking Association of South Africa, 2014). Loan application information applicable to SMEs were obtained from banks' websites, supplemented by hard copy applications available from the banks themselves. The information required for an SME to apply for a loan in terms of these loan applications was subsequently scrutinised, and clarified by discussions with applicable loan officers.
The remainder of the article will, therefore, reflect on whether audited financial statements hold any advantage to South African SMEs in applying for bank finance, before providing some concluding remarks.

\section{Results}

It was indicated earlier that banks will often request updated financial statements or management accounts when assessing an application, and even require audited or reviewed financial statements. However, it is not clear whether these requirements are actually a make or break consideration in lending decisions by banks.

From a South African perspective, the following table provides a summary of the essential responses of the banks to the proposed application as far as the financial information required.

Table 1. Bank requirements in consideration of SME finance application

\begin{tabular}{|l|l|l|l|l|}
\hline \multicolumn{1}{|c|}{ Description } & Bank 1 & \multicolumn{1}{|c|}{ Bank 2 } & \multicolumn{1}{c|}{ Bank 3 } & \multicolumn{1}{c|}{ Bank 4 } \\
\hline $\begin{array}{l}\text { Audited financial state- } \\
\text { ments }\end{array}$ & No & No & No & $\begin{array}{l}\text { No - possibly } \\
\text { for new clients }\end{array}$ \\
\hline $\begin{array}{l}\text { Independently reviewed } \\
\text { financial statements }\end{array}$ & Yes & Yes & Yes & Yes \\
\hline Cashflow statement & Yes & Yes & Yes & Yes \\
\hline Management statements & Yes & $\begin{array}{l}\text { No - unless } \\
\text { financial } \\
\text { statements } \\
\text { are dated }\end{array}$ & $\begin{array}{l}\text { No - unless } \\
\text { financial } \\
\text { statements } \\
\text { are dated }\end{array}$ & $\begin{array}{l}\text { No- unless } \\
\text { financial } \\
\text { statements are } \\
\text { dated }\end{array}$ \\
\hline Business plan & Yes & Yes & Yes & No \\
\hline $\begin{array}{l}\text { Financial information of } \\
\text { directors/members/partners }\end{array}$ & Yes & Yes & Yes & Yes \\
\hline Security required & Yes & Yes & Yes & Yes \\
\hline
\end{tabular}

In consideration of the above information, the following:

- Audited financial statements: none of the banks insisted on audited financial statements as a prerequisite.

- Independent review financial statements: although the banks required financial statements, there was no insistence on audited financial statements and independent review statements were accepted.

- Cashflow projection: all the banks required cashflow projections.

- Management statements: all the banks required the most recent management statements.

- Business plan: three of the four banks required, indicating that this was something deemed of value.

- Financial information for directors, members and/or partners: all the banks indicated that the financial position of stakeholders is an important consideration.

- Security requirement: all the banks required adequate availability of suitable collateral. 
Therefore, it may be deduced that South African banks have become more risk adverse and are leaning away from relationship lending and more towards a riskbased lending strategy. If one scrutinizes the above requirements more intently, one finds that historic information (i.e., audited financial statements) is less prevalent than current and future information (i.e., cashflows, management accounts and owner security). For an SME to have a bank consider its funding application favorably, it will have to be able to indicate i) that adequate security is in place, including the financial position of key stakeholders, and ii) that repayment of loans can be reasonably guaranteed from an anticipated cashflow perspective.

\section{Concluding remarks and future research}

South African policy-makers have attempted to ease the regulatory burden of SMEs by abolishing the statutory audit, which placed a burden on SMEs in terms of fees, accounting systems and timeframe pressures. This change in the Act, as well intended as it may be, had the potential of creating a damned if you do, damned if you don't situation. SMEs could easily get caught up between what the new Act requires as far as financial reporting is concerned versus what financial institutions may require as far as access to finance is concerned.

This paper focused on the potential impact on SMEs' accessibility to bank finance in light of doing away with the statutory audit for qualifying entities. In investigating this potential impact, both a liteture study and empirical investigation were conducted. A review of relevant published research indicated the following key points:

- SMEs play a crucial role in the economy of most countries throughout the world.

- Even on a global scale, access to finance is a major concern for SMEs, and they mostly rely on banks as an important source of external funding for their operations.

- Banks seem to have tightened their lending criteria, and have historically favored audited financial statements as supportive when considering related SME fund applications.

Notwithstanding the above indications, the results section of this study indicates that audited financial statements may have lost its appeal as a key reliance criterion for banks when assessing finance applications. The investigation into the banks' requirements indicated the following:

- Banks currently view historical information, as provided in the audited financial statements, of lesser value in comparison to the current and future anticipated performance of the SME. This is seen in the emphasis placed on current management accounts and cashflow projections.
- The ability to provide adequate security also seems to carry more weight than the historical information portrayed by financial statements. Consequently, the requirement for key stakeholders to declare their personal financial position as part of credit application processes is needed.

Seen in light of the above, it may be argued that, after the 2008 credit crisis, banks have perhaps become more risk adverse and will almost to a fault only lend money if enough security has been made available by the applicant, including its sustainability vision, not its historical successes.

From the above, we can infer that banks have adapted to the requirements of the Act and no longer insist on audited SME financial statements, and do accept independently reviewed financial statements. Armed with this knowledge, SMEs can now make more informed decisions as to whether they want to bear the financial burden of an audit engagement. Although cases may differ from bank to bank, and from client to client, the overall consensus from banks seems to be that audited financial statements are no longer a prerequisite for a successful loan application. It seems, against expectations, that audited financial statements are no longer the boogieman causing SMEs to lie awake at night. Although the question of how to access bank funding still remains for most SMEs, at least to audit or not to audit is not the question anymore.

This research acknowledged that the problem of accessibility to finance is a global SME problem and the invaluable contribution SMEs have on global employment and GDP levels. This being said, it is important to bear in mind that the approach of banks towards the value of audited financial statements in terms of SME financing applications was restricted to a South African perspective. Banks in different countries may have different views on the value of audited financial statements.

The research was also localized on bank funding applications. The conclusions drawn may, therefore, not be applicable to other avenues of SME funding. As such, the research in no way tries to indicate that an audit has lost all value to SMEs. The value of an audit may still be found in various other applications, such as providing accurate management decision-making, potential tax-saving benefits, prevention of theft and corruption in an organization, and the structuring of equity transactions.

The research also looked at the problem a bank perspective. Future research can been undertaken to investigate the same problem from an SME perspective - it may be that what the banks preach in terms of the requirements may not be what they practice when SMEs apply for funding. 


\section{References}

1. Abor, J., \& Quartey, P. (2010). Issues in SME Development in Ghana and South Africa. International Research Journal of Finance and Economics, 39, 218. Retrieved from http://connection.ebscohost.com/c/articles/50746389/issues-sme-development-ghana-south-africa

2. Bankseta. (n.d.). Small and Micro Enterprises (SMEs). Retrieved from http://www.bankseta.org.za/downloads/Small_and_Micro_Enterprises_Brochure.pdf.

3. Beck, T., Demirgüç-Kunt, A., \& Maksimovic, V. (2005). Financial and legal constraints to growth: Does firm size matter? The Journal of Finance, 60(1), 137-177.

4. Berger, A. N., \& Udell, G. F. (2004, October). A more complete conceptual framework for SME finance. Paper presented at the World Bank conference on Small and Medium Enterprises: Overcoming Growth Constraints, World Bank, MC.

5. Berger, A., \& Udell, G. (2006). A more complete conceptual framework for SME finance. Journal of Banking and Finance, 30(11), 2945-2966.

6. Berger, N., \& Frame, W. S. (2005). Small business credit scoring and credit availability (Working paper No. 2005-10). Retrieved from https://www.business-school.ed.ac.uk/waf/crc_archive/2005/presentations/berger-frame.pdf

7. Bernstein, A. (2016). South Africa's unemployment crisis the worst in the world. The Sowetan. Retrieved from http://www.sowetanlive.co.za/news/2016/04/13/south-africa-s-unemployment-crisis-the-worst-in-the-world (November 25, 2016).

8. Berry, A., Von Blottnitz, M., Cassim, R., Kesper, A., Rajaratnam, B., \& Seventer, D. E. (2002). The economics of SMMES in South Africa. Retrieved from http://www.tips.org.za/files/506.pdf

9. Chimucheka, T., \& Rungani, E. C. (2011). The impact of inaccessibility to bank finance and lack of financial management knowledge to small, medium and micro enterprises in Buffalo City Municipality, South Africa. African Journal of Business Management, 5(14), 5509-5517.

10. Claymore, E. (2016). Unemployment in South Africa vs the rest of the world. The South African. Retrieved from http://www.thesouthafrican.com/unemployment-in-south-africa-vs-the-rest-of-the-world/ (October 25, 2016).

11. Collis, J., Jarvis, R., \& Page, M. (2013). SMEs, financial reporting and trade credit: An international study (Research Report No. 133). Retrieved from Association of Chartered Certified Accountants http://www.accaglobal.com/ab77

12. European Union, Directorate-General for Enterprise (2002). Innovation Tomorrow. Luxembourg: Office for the Official Publications of the European Communities.

13. Falkena, H. I., Abedian, M., Blottnitz, C., Coovadia, G., Davel, J., Madungandaba, E., Rees, S. (2001). SMEs' Access to Finance in South Africa, A Supply-Side Regulatory Review. Retrieved from http://www.treasury.gov.za/publications/other/Access\%20to\%20Finance\%20in\%20South\%20Africa\%20\%20A\%20Supply-Side\%20Regulatory\%20Review.pdf

14. Fatoki, O., \& Asah, F. (2011). The impact of firm and entrepreneurial characteristics on access to debt finance by SMEs in King Williams' Town, South Africa. International Journal of Business and Management, 6(8), 170-179.

15. Fatoki, O., \& Garwe, D. (2010). Obstacles to the growth of new SMEs in South Africa: A principal Component analysis approach. African Journal of Business Management, 4(5), 729-738.

16. Feschijan, D. (2008). Analysis of the creditworthiness of bank loan applicants. Facta Universitatis: Economics and Organization, 5(3), 273-280.

17. Finmark. (2010). FinScope South Africa Small Business Survey. Retrieved from http://www.finmark.org.za/sites/wp-content/uploads/pubs/FinScope-Brochure-final-28-09-2010.pdf

18. Global Entrepreneurship Monitor. (2014). An alarmingly low level of entrepreneurial activity in spite of high unemployment. Retrieved from http://www.gemconsortium.org/country-profile/108.

19. Guiral-Contreras, A., Gonzalo-Angulo, J. A., \& Rodgers, W. (2007). Information content and recency effect of the audit report in loan rating decisions. Accounting and Finance, 47(2), 285-304.

20. Haynes, G. W., Ou, C., \& Berney, R. (1999). Small business borrowing from large and small banks. Business Access to Capital and Credit, 287-327.

21. Industry Canada. (2013). Key small business statistics. Retrieved from https://www.ic.gc.ca/eic/site/061.nsf/425f69a205e4a9f48525742e00703d75/3e99b2ebe27d038d85257bf0004f33ee /\$FILE/KSBS-PSRPE_July-Juillet2012_eng.pdf

22. Institute of Chartered Accountants in England and Wales (ICAEW). (2009). SME access to finance research report.

23. International Federation of Accountants. (2010). The Banker/IFAC survey shows small business lending holds steady; Accountants play key role in lending decisions. Retrieved November 14, 2014 from http://www.ifac.org/newsevents/2009-10/bankerifac-survey-shows-small-business-lending-holds-steady-accountants-play-key.

24. Kim, N. J., \& Elias, R. Z. (2008). Financial statements, attestation level and lending decision by small banks. Southwest Business and Economics Journal, 16, 63-72.

25. Mahembe, E. (2011). Literature review on small and medium enterprises' access to credit and support in South Africa. Retrieved from http://www.ncr.org.za/pdfs/Literature\%20Review\%20on\%20SME\%20Access\%20 to\%20Credit\%20in\%20South\%20Africa_Final\%20Report_NCR_Dec\%202011.pdf

26. Maudos, J. (2013). Spanish SMEs' financial restrictions: The importance of bank credit. Spanish Economic and Financial Outlook, 2(1), 28-39. 
27. Mazanai, M., \& Fatoki, O. (2012). Access to finance in the SME Sector: A South African perspective. Asian Journal of Business Management, 4(1), 58-67.

28. Mazaroll, T. (2012). Financing the small business sector: What has been the impact of GFC? Retrieved from http://theconversation.com/financing-the-small-business-sector-what-has-been-the-impact-of-the-gfc-6894 (January 16, 2016).

29. Mills, K. G., \& McCarthy, K. (2014). The state of small business lending: Credit access during the recovery and how technology may change the game (Working paper No. 15-004). Retrieved from http://www.hbs.edu/faculty/Publication\%20Files/15-004_09b1bf8b-eb2a-4e63-9c4e-0374f770856f.pdf

30. NFIB. (2012). Small business, credit access, and a lingering recession. Retrieved from http://www.nfib.com/Portals/0/PDF/AllUsers/research/studies/small-business-credit-study-nfib-2012.pdf

31. FSB. (2016). UK Small Business Statistics. Retrieved from http://www.fsb.org.uk/media-centre/small-businessstatistics (November 16, 2016).

32. SBA. (2011). Frequently asked questions about small business finance. Retrieved from https://www.sba.gov/sites/default/files/2014_Finance_FAQ.pdf.

33. OECD. (2009). The impact of the global crisis on $\mathrm{SME}$ and entrepreneurship financing and policy responses. Retrieved from www.oecd.org/cfe/smes/43183090.pdf.

34. Robu, M. (2013). The Dynamics and Importance of SMEs in Economy. The USV annals of economics and public administration, 13(1), 84-89.

35. Shakespeare, W. (1985) Macbeth. F. C. H. Rumboll (Eds.). Cape Town: Maskew Miller Longman. C.

36. South Africa. (2008). Companies Act 2008: Act. Pretoria: Government Press.

37. SAICA. (2010). To audit or not to audit? Retrieved from https://www.saica.co.za/tabid/695/itemid/2405/language/en-ZA/To-audit-or-not-to-audit.aspx.

38. SAIPA. (2011). Independent review of annual financial statements. Retrieved from https://www.saipa.co.za/articles/177648/independent-review-annual-financial-statements

39. Stiglitz, J. E., \& Weiss, A. (1981). Credit rationing in markets with imperfect information. The American Economic Review, 71(3), 393-419.

40. The Banking Association of South Africa. (2014). South African Banking Sector Overview. Retrieved from http://www.banking.org.za/docs/default-source/publication/banking-sector-overview.pdf?sfvrsn=6.

41. The Department of Finance. (2013). SME credit demand survey October 2012 - March 2013. Retrieved from http://www.finance.gov.ie/sites/default/files/SMEdemandREDCjun_0.pdf

42. Tsaia, H., \& Huab, M. (2009). The Effects of Audit Quality on Loan Interest Rates for Small and Medium-Sized Enterprises in Taiwan. International Journal of Business, 14(3), 265-281.

43. Turton, N., \& Herrington, M. (2012). Global Entrepreneurship Monitor: South Africa. Retrieved from http://www.gsb.uct.ac.za/files/2012GEMSouthAfricaReport.pdf.

44. Wattanapruttipaisan, T. (2003). Four proposals for improved financing of SME development in ASEAN. Asian Development Review, 20(2), 1-45.

45. Wiersch, A. M., \& Shane, S. (2013). Why small business lending isn't what it used to be. Economic Commentary, 10. Retrieved from http://econpapers.repec.org/article/fipfedcec/y_3a2013_3ai_3aaug14_3an_3a2013-10.htm

46. Wignaraja, G., \& Jinjarak, Y. (2015). Why do SMEs not borrow more from banks? Evidence from the People's Republic of China and Southeast Asia (ADBI Working Paper No. 509). Retrieved from https://www.econstor.eu/bitstream/10419/115330/1/815332033.pdf

47. World Bank. (1994). Can intervention Work? The role of government in SME Success. World Bank Group: Washington, DC.

48. World Bank. (2002). Review of Small Business Activities. World Bank Group: Washington, DC.

49. World Bank. (2004). Review of Small Business Activities. World Bank Group: Washington, DC.

50. Wright, M., \& Davidson, R. (2000). The effect of auditor attestation and tolerance for ambiguity on commercial lending decision. Auditing: A Journal of Practice and Theory, 19(2), 67-81. 